\title{
Prevalensi, Spektrum Klinis dan Gambaran Neurofisiologi Kasus Neuromuskular
}

\author{
Mia Milanti Dewi, Dwi Putro Widodo, Roy Amardiyanto, Nurcahaya Sinaga, Nurul Hidayah \\ Departemen Ilmu Kesehatan Anak Fakultas Kedokteran Universitas Indonesia/Rumah Sakit Dr. Cipto Mangunkusumo, \\ Jakarta
}

Latar belakang. Sebagian kasus neuromuskular dapat ditegakkan berdasarkan klinis. Pemeriksaan penunjang, pemeriksaan imunologi dan analisis genetik sangat penting diperiksa untuk memastikan diagnosis. Ini merupakan penelitian pertama mengenai prevalensi penyakit neuromuskular di Indonesia.

Tujuan. Mengetahui prevalensi, spektrum klinis, dan gambaran neurofisiologi kasus neuromuskular di RSCM periode Januari Desember 2017.

Metode. Penelitian ini bersifat retrospektif dari Januari - Desember 2017.

Hasil. Di tahun 2017 terdapat 179 pasien (usia 1 bulan - 18 tahun) yang dirujuk untuk dilakukan pemeriksaan elektromiografi, dan 130 pasien memenuhi kriteria diagnostik penyakit neuromuskular. Dari seluruh pasien kelainan neuromuskular yang sering ditemukan berturut-turut adalah neuropati perifer (22,2\%), Duchenne muscular dystrophy (15,6\%), brachialis plexus injury (15,2\%), Bell's palsy (7,6\%), Erb Palsy (6,1\%), chronic inflamatory demyelinating polyneuropathy (5,4\%), spinal muscular atrophy type 1 (4,6 $\%)$, spinal muscular atrophy type 2 (3,8\%), miastenia gravis okular (3,8\%), Limb Girdle muscular dystrophy (3,1\%), sindrom Guillain Barre (3,1\%), sindrom Guillain Barre-tipe acute motor axonal neuropathy (2,3\%), sindrom Guillain Barre-tipe acute motor-sensory axonal neuropathy $(1,5 \%)$, miastenia gravis umum (1,5\%), Charcot Marie tooth (1,5\%), miotonia kongenital (1,5\%), dan miositis viral akut $(1,5 \%)$.

Kesimpulan. Prevalensi kelainan neuromuskular anak RSCM sebesar 2,6 \% dari seluruh pasien yang dilakukan datang ke poli saraf anak. Lima terbanyak kelainan neuromuskular adalah neuropati perifer, Ducchenne Muscular dystrophy, spinal muskular atrofi, sindrom Guillain Barre, dan chronic inflamatory demyelinating polyneuropathy. Sari Pediatri 2018;20(4):214-20

Kata kunci: kelainan neuromuskular, prevalensi, spektrum klinis, neurofisiologi

\section{Prevalence, Clinical Spectrum, and Neurophysiology Features Neuromuscular Cases}

Mia Milanti Dewi, Dwi Putro Widodo, Roy Amardiyanto, Nurcahaya Sinaga,Nurul Hidayah

Background. Most of the cases could be confirmed with a clinical symptom. Neurophysiological examination, immunological examination dan genetic analysis are essentials to confirm the diagnosis. This study is the first study about prevalence of neuromuscular diseases in Indonesia.

Objective. To get the prevalence, clinical spectrum, and neurophysiology case picture in RSCM during January - December 2017. Methods. This study was a restrospective study collected from January - Desember 2017.

Results. In 2017 there were 179 patients (age 1 months to 18 years old), dan 130 patients met the criteria. The most frequent neuromuscular disorder found was peripheral neuropathy (22,2\%), Duchenne muscular dystrophy (15,6\%), brachialis plexus injury $(15,2 \%)$, Bell's palsy $(7,6 \%)$, Erb palsy $(6,1 \%)$, chronic inflammatory demyelinating polyneuropathy $(5,4 \%)$, spinal muscular atrophy type 1 (4,6\%), SMA type 2 (3,8\%), ocular myasthenia gravis (3,8\%), limb-girdle muscular dystrophy $(3,1 \%)$, Guillain Barre syndrome - acute motor axonal neuropathy (2,3\%), Guillain Barre syndrome acute motor-sensory axonal neuropathy (1,5\%), generalized myasthenia gravis (1,5\%), Charcot Marie tooth (1,5\%), congenital myotonia (1,5\%) and acute viral myositis $(1.5 \%)$ respectively. Conclusion. Prevalence of pediatric neuromuscular disorder in RSCM was $2.6 \%$ of all patients who came to neurology outpatient ward. Five of the most common neuromuscular disorder was peripheral neuropathy, Duchenne muscular dystrophy, spinal muscular atrophy, Guillain Barre syndrome, and chronic inflammatory demyelinating polyneuropathy. Sari Pediatri 2018;20(4):214-20

Keywords: neuromuscular disorder, prevalence, clinical spectrum, neurophysiology

Alamat korespondensi: Mia Milanti Dewi. Departemen Ilmu Kesehatan Anak FK Universitas Indonesia-RS.Cipto Mangunkusumo, Jakarta. Email: miamilanti@gmail. com 
K asus neuromuskular sering ditemukan pada anak. Sebagian besar kasus neuromuskular dapat dikenali hanya dari gejala klinis dan kornu anterior medulla spinalis dan bera kornu anterior medulla spinalis dan berakhir di neuromuskular junction. ${ }^{1,2}$ Kelainan neuromuskular dapat terjadi secara genetik maupun didapat. Klasifikasi kelainan dibedakan berdasarkan anatomi, yaitu kelainan yang terjadi di motor neuron (spinal muscular atrophy/SMA), saraf perifer (Bell's palsy, Erb's palsy, sindrom Guillain Barre /SGB, chronic inflammatory demyelinating polyneuropathy/CIDP, Charcot Marie tooth disease/CMT), neuromuscular junction (miastenia gravis/MG) dan otot (Duchenne muscular dystrophyl DMD, miotonia kongenital, limb girdle muscular dystrophy/LGMD). ${ }^{2}$ Masing-masing kelainan memiliki gambaran yang khas secara klinis, pemeriksaan neurologis maupun pemeriksaan penunjang. ${ }^{1-2}$

Prevalensi kasus neuromuskular pada anak adalah 1:3000 anak. $^{2}$ Prevalensi maupun insiden masingmasing kelainan neuromuskular dapat berbeda di tiap negara. Insiden miastenia gravis tipe okular ditemukan 88\% di Cina. Di tahun 2010, prevalensi kasus Duchenne muscular dystrophy dan Becker muscular dystrophy di Amerika Serikat sebesar 1,38 per 10.000 laki-laki berusia 5-24 tahun. ${ }^{3}$ Di Cina ditemukan 68\% kelainan neuromuskular adalah genetik dan 32\% bukan genetik. Kelainan genetik yang banyak ditemui adalah Duchenne muscular dystrophy, Becker muskular dystrophy, spinal muscular atrophy. Prevalensi secara keseluruhan di Cina adalah 1 dalam 4669 anak. ${ }^{4}$ Pada tahun 2016, Woodcock dkk, menemukan prevalensi kasus neuromuskular pada anak sebesar 36,9/100,000 di daerah Yorkshire. Insiden SGB usia 0-15 tahun di Amerika latin, Amerika Serikat, Finlandia, dan Taiwan sebesar 0,34-1,34/100,000 anak. ${ }^{7}$ Pada SGB, 90\%95\% mengalami pemulihan dalam kurun waktu 6-12 bulan. ${ }^{7}$ Sebagian kecil SGB akan berlanjut menjadi CIDP yang dapat mengalami perbaikan klinis yang lambat. Perjalanan klinis DMD sangat lambat dan menyebabkan kematian di usia sekitar 20 tahun. $^{8}$

Kelainan neuromuskular di Indonesia juga cukup banyak, tetapi masih belum ada data mengenai prevalensi kasus neuromuskular pada anak. Mengetahui spektrum klinis kelainan neuromuskular sangatlah penting untuk menentukan diagnosis awal dan prognosis pasien selanjutnya. Pemeriksaan penunjang yang penting dilakukan, antara lain, pemeriksaan laboratorium dan neurofisiologi. ${ }^{9}$ Di Indonesia, tidak semua rumah sakit memiliki pemeriksaan neurofisiologi sehingga spektrum klinis yang khas pada kasus neuromuskular berperan penting. Pemeriksaan neurofisiologi yang paling penting dilakukan, yaitu pemeriksaan elektromiografi (EMG). Penelitian ini ingin mengetahui prevalensi, spektrum klinis, dan neurofisiologi kasus neuromuskular pada anak yang datang ke poli neurologi RSCM periode Januari Desember 2017. Ini merupakan penelitian kasus neuromuskular pertama di Indonesia.

\section{Metode}

Penelitian bersifat retrospektif dengan mengambil data rekam medis pasien anak yang datang ke Poli Neurologi Anak RSCM dan dilakukan pemeriksaan neurofisiologi selama periode Januari-Desember 2017. Kriteri inklusi adalah anak usia $<18$ tahun dan didiagnosis kelainan neuromuskular. Pengelompokan diagnostik dilakukan oleh dokter konsultan saraf anak. Penentuan diagnosis kerja berdasarkan klinis dan atau kreatinin kinase dan atau pemeriksaan neurofisiologi (EMG dan KHS), dan atau pemeriksaan imunologi (asetilkolin antibodi reseptor) dan atau pemeriksaan genetik. Pasien yang ternyata bukan merupakan kelainan neuromuskular akan dieksklusi.

\section{Hasil}

Selama periode 1 tahun (Januari - Desember 2017) terdapat 179 pasien yang dicurigai mengalami kelainan neuromuskular. Seluruh pasien dilakukan pemeriksaan elektromiografi di Poli Elektromiografi Neurologi RSCM Jakarta. Terdapat 130 pasien memenuhi kriteria kelainan neuromuskular.

Kunjungan pasien ke poli neurologi dalam kurun waktu 1 tahun (Januari - Desember 2017) sebanyak 6813 pasien. Berdasarkan hasil pada Gambar 1, $130(2,6 \%)$ pasien terbukti memiliki kelainan neuromuskular dengan berbagai macam spektrum klinisnya (Tabel 1). Sebagian besar pasien merupakan rujukan dari luar RSCM. Domisili pasien sangat bervariasi, mulai dari di dalam kota Jakarta hingga dari Sumatra maupun Kalimantan.

Sebagian besar pasien anak yang dilakukan pemeriksaan neurofisiologi berusia $>5$ tahun dengan 
Mia Milanti Dewi dkk: Prevalensi, spektrum klinis dan gambaran neurofisiologi kasus neuromuskular

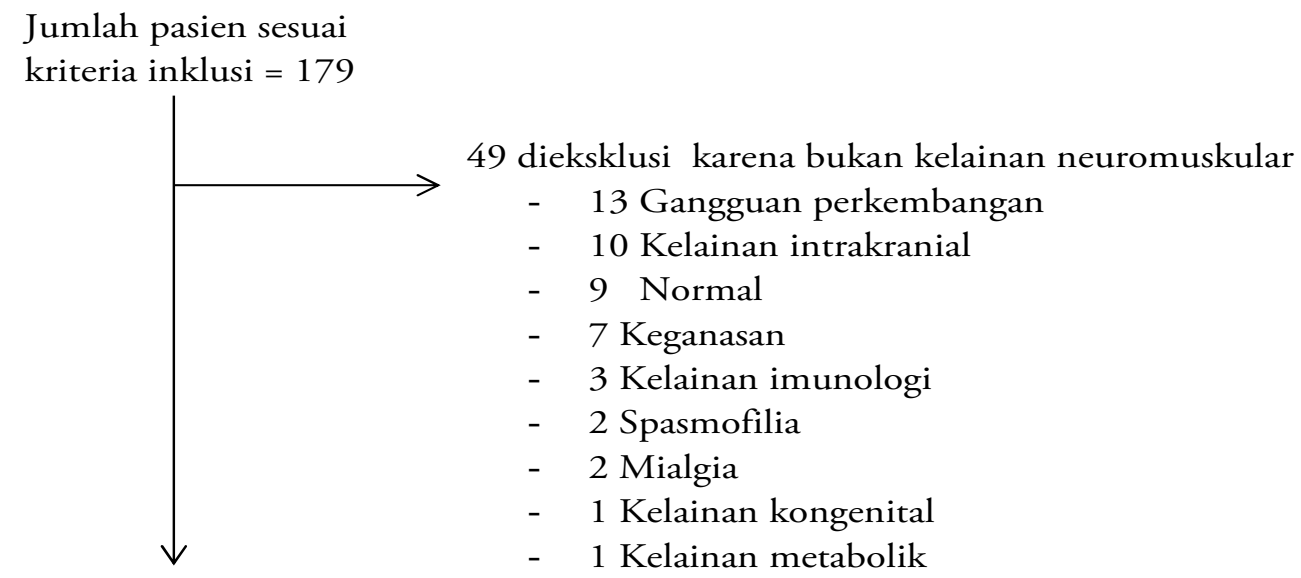

Data yang diolah 130

Gambar 1. Jumlah pasien penelitian

usia tertua adalah 17 tahun. Laki-laki lebih banyak dibandingkan perempuan. Pengelompokan kriteria diagnostik menunjukkan kelainan neuromuskular yang berada di motor neuron, saraf perifer, neuromuskular junction dan pada otot. Pada penelitian ini insiden DMD terlihat cukup banyak (12,3\%).

Pengelompokkan kelainan neuromuskular berdasarkan spektrum klinis tertera pada Tabel 2. Setiap penyakit memiliki ciri khas masing-masing. Pemeriksaan penunjang selain pemeriksaan neurofisiologi tidak selalu dilakukan pada penelitian ini. Pemeriksaan KHS, EMG, serta RNS dilakukan oleh dokter spesialis saraf anak konsultan di bidang saraf anak dan neurofisiologi.

Beberapa kelainan neuromuskular telah dilakukan pemeriksaan genetik, seperti DMD dan SMA. Dari 11 pasien SMA tipe 1 serta tipe 2, 3 (27,3\%) pasien telah dilakukan analisis DNA yang membuktikan adanya kelainan pada gen SCN. Pada 16 pasien DMD, hingga saat ini, belum terdapat hasil pemeriksaan analisis genetiknya. Kelainan genetis, seperti CMT yang ditemukan pada 1 keluarga, masih belum dilakukan pemeriksaan analisis genetiknya.

\section{Pembahasan}

Kelainan neuromuskular pada anak merupakan kelainan yang cukup sering dijumpai. Insiden 1 : 3000 dari kelahiran anak. ${ }^{2}$ Insiden tiap negara dapat berbeda. Indonesia sebagai negara berkembang masih belum memiliki data insiden tersebut. Tidak semua daerah memiliki alat penunjang diagnostik, seperti neurofisiologi, pemeriksaan analisis DNA, ataupun pemeriksaan laboratorium lainnya. Jakarta yang merupakan ibukota negara memiliki rumah sakit rujukan nasional, yaitu Rumah Sakit Dr. Cipto Mangunkusumo (RSCM). Sejak 2017, RSCM memiliki alat neurofisiologi yang dapat melakukan pemeriksaan elektromiografi (EMG), kecepatan hantaran sarar (KHS), dan repetitive stimulation nerve (RNS). Kelainan neuromuskular pada anak dapat dikenali hanya dari manifestasi klinisnya, pemeriksaan penunjang (neurofisiologi, analisis DNA, dan pemeriksaan laboratorium lainnya) sangat berguna untuk melengkapi diagnosis.

Rumah Sakit Umum Pusat Cipto Mangunkusomo Jakarta sebagai pusat rujukan nasional telah melakukan pemeriksaan elektromiografi (EMG) sejak beberapa dekade, tetapi sempat terhenti beberapa tahun karena keterbatasan alat. Mulai Januari 2017, pemeriksaan elektromiografi telah dimulai dengan menggunakan alat pemeriksaan yang baru. Penelitian ini mengambil data hasil pemeriksaan dari alat elektromiografi yang baru. Meskipun penelitian ini masih terbatas di satu rumah sakit di kota Jakarta dan belum mewakili populasi Jakarta dan Indonesia secara keseluruhan, tetapi mengetahui secara dini spektrum klinis maupun neurofisiologi kasus neuromuskular anak sangatlah penting untuk memberikan luaran yang lebih baik pada anak. 
Tabel 1. Karakteristik pasien

\begin{tabular}{|c|c|c|}
\hline Karakteristik & Jumlah & Persentase \\
\hline \multicolumn{3}{|l|}{ Jenis kelamin } \\
\hline Laki-laki & 74 & 56,9 \\
\hline Perempuan & 56 & 43,1 \\
\hline \multicolumn{3}{|l|}{ Umur (tahun) } \\
\hline$\leq 5$ & 39 & 30,0 \\
\hline$>5$ & 91 & 70,0 \\
\hline \multicolumn{3}{|l|}{ Diagnosis klinis } \\
\hline \multicolumn{3}{|l|}{ Penyakit motor neuron } \\
\hline SMA tipe 1 & 6 & 4,6 \\
\hline SMA tipe II & 5 & 3,8 \\
\hline \multicolumn{3}{|l|}{ Polineuropati } \\
\hline \multicolumn{3}{|l|}{ Neuropati perifer } \\
\hline Trauma & 13 & 10 \\
\hline Obat & 11 & 8,5 \\
\hline Sistemik & 19 & 14,6 \\
\hline Brachialis plexus injury & 10 & 7,7 \\
\hline Erb's palsy & 4 & 3,1 \\
\hline Bell's palsy & 5 & 3,8 \\
\hline Keganasan & 4 & 3,1 \\
\hline \multicolumn{3}{|l|}{ Sindrom Guillain Barre } \\
\hline AIDP & 4 & 3,1 \\
\hline AMAN & 3 & 2,3 \\
\hline AMSAN & 2 & 1,5 \\
\hline CIDP & 7 & 5,3 \\
\hline CMT & 2 & 1,5 \\
\hline \multicolumn{3}{|l|}{ Neuromuscular junction } \\
\hline MG okular & 5 & 3,8 \\
\hline MG umum & 2 & 1,5 \\
\hline \multicolumn{3}{|l|}{ Otot } \\
\hline Miotonia kongenital & 2 & 1,5 \\
\hline DMD & 16 & 12,3 \\
\hline LGMD & 4 & 3,1 \\
\hline Akut viral myositis & 2 & 1,5 \\
\hline
\end{tabular}

Keterangan: SMA: Spinal muscular dystrophy; SGB: Sindrom Guillain Barre; AIDP: acute inflammatory demyelinating polyneuropathy; AMAN: Acute motoric axonal neuropathy; AMSAN: Acute motoric and sensoric neuropathy; CIDP: Chronic inflammatory demyelinating polyneuropathy; CMT: Charcot Marie tooth; DMD: Duchenne muscular dystrophy; LGMD: Limb girdle muscular dystrophy

Selama tahun 2017, prevalensi kelainan neuromuskular anak di RSCM sebesar 2,6\%. Namun begitu, RSCM hanya salah satu rumah sakit terbesar yang berada di kota Jakarta sehingga tidak mewakili kondisi populasi di kota Jakarta pada umumnya. Pasien datang berobat ke RSCM dari berbagai daerah di Indonesia karena RSCM merupakan rumah sakit rujukan nasional. Jenis kelainan neuromuskular dikelompokkan berdasarkan kelainan anatomi yang dimulai dari penyakit motor neuron, saraf perifer, neuromuscular junction, dan otot. Kelainan terbanyak yang ditemui pada penelitian ini adalah DMD (14,6\%). Di tahun 2010, prevalensi kasus duchenne muscular dystrophy dan becker muscular dystrophy di Amerika Serikat sebesar 1,38 per 10.000 lakilaki berusia 5-24 tahun. ${ }^{3}$ Sementara di Cina 68\% merupakan kelainan muskular genetik.

Secara klinis, DMD sangat mudah dikenali. Kelainan neuromuskular yang didominasi oleh laki-laki diawali dengan gejala kesulitan berjalan, anak terlihat 
Mia Milanti Dewi dkk: Prevalensi, spektrum klinis dan gambaran neurofisiologi kasus neuromuskular

Tabel 2. Spektrum klinis dan pemeriksaan penunjang yang khas pada kasus neuromuskular

\begin{tabular}{|c|c|c|c|c|c|c|c|c|c|c|c|c|c|}
\hline \multirow[t]{2}{*}{ Diagnosis } & \multicolumn{4}{|c|}{ Anamnesis } & \multicolumn{5}{|c|}{ Pemeriksaan fisis } & \multicolumn{4}{|c|}{ Pemeriksaan penunjang } \\
\hline & $\begin{array}{l}\text { Kelemah- } \\
\text { an }\end{array}$ & $\begin{array}{c}\text { Motorik } \\
\text { terlambat }\end{array}$ & $\begin{array}{c}\text { Gangguan } \\
\text { berjalan }\end{array}$ & Lainnya & Parese & Simetris & $\begin{array}{l}\text { Gower } \\
\text { sign }\end{array}$ & Gait & Lainnya & CK & LCS & DNA & $\begin{array}{c}\mathrm{Ab} \\
\text { Reseptor } \\
\text { Ach }\end{array}$ \\
\hline SMA tipe 1 & + & + & - & $<6$ bulan & + & + & - & - & $\begin{array}{l}\text { Inferior> } \\
\text { superior }\end{array}$ & + & - & + & - \\
\hline SMA tipe 2 & + & + & - & $>6$ bulan & + & + & - & - & $\begin{array}{l}\text { Inferior> } \\
\text { superior }\end{array}$ & + & - & + & - \\
\hline SGB & + & - & + & Asending & + & + & + & + & Hipo/areflexia & - & - & - & - \\
\hline CIDP & + & - & + & $\begin{array}{c}>4 \\
\text { minggu }\end{array}$ & + & + & + & + & Hipo/areflexia & - & + & - & - \\
\hline CMT & + & \pm & + & & + & + & - & + & $\begin{array}{c}\text { Champagne } \\
\text { bottle di } \\
\text { ekstremitas } \\
\text { bawah }\end{array}$ & - & - & - & - \\
\hline Bell's palsy & + & - & - & Akut & + & - & - & - & N 7 sentral & - & - & - & - \\
\hline Erb's palsy & + & - & - & Neonatus & + & - & - & - & - & - & - & - & - \\
\hline Neuropati & + & - & \pm & Obat & + & \pm & + & + & - & - & - & - & - \\
\hline $\begin{array}{l}\text { Miastenia } \\
\text { Gravis }\end{array}$ & + & - & \pm & Fluktuatif & + & \pm & \pm & \pm & Ptosis \pm & - & - & - & + \\
\hline $\begin{array}{l}\text { Miotonia } \\
\text { Kongenital }\end{array}$ & - & - & - & Kaku & - & - & - & - & Hipertrofi otot & - & - & - & - \\
\hline DMD & + & + & + & $\hat{0}$ & + & + & \pm & + & $\begin{array}{l}\text { Pseudohipertrofi } \\
\text { otot }\end{array}$ & $\uparrow \uparrow$ & - & + & - \\
\hline LGMD & + & + & + & 이시 & + & + & \pm & + & $\begin{array}{c}\text { Proximal > } \\
\text { distal }\end{array}$ & $\uparrow /+$ & - & - & - \\
\hline Miositis & - & - & - & Nyeri & - & - & - & - & - & - & - & - & - \\
\hline
\end{tabular}

Keterangan : + : ada/abnormal; - : tidak ada/normal; \pm : mungkin ada atau tidak ada. $\uparrow:$ sedikit meningkat ; $\uparrow \uparrow:$ sangat meningkat. Tabel 2 menunjukkan gambara khas pada masing-masing kelainan neuromuskular.

sering jatuh, dan semakin bertambah waktu anak semakin tidak bisa berjalan. Saat awal terjadi kelainan, terlihat adanya gower sign, tetapi pada keadaan berat, gower sign mungkin sudah tidak ditemukan lagi. Kelainan lain yang khas, yaitu adanya pseudohipotrofi, serta walding gait. Pada penelitian ini, 19 pasien DMD memiliki kelainan klinis yang khas ditunjang adanya gambaran miopati pada EMG meskipun pemeriksaan analisis DNA belum dilakukan. Gambaran miopati pada EMG terlihat adanya amplitude CMAP yang rendah, adanya PSW saat istirahat.

Dari ke sembilan pasien dengan SGB, setelah dilakukan EMG didapat 4 pasien dengan tandatanda demyelinisasi dan 5 pasien mengalami kelainan aksonal. Berdasarkan Willison $\mathrm{dkk},{ }^{11}$ prognosis SGB yang mengalami demyelinisasi lebih baik dibandingkan kelainan aksonal, seperti AMAN atau AMSAN. Pada penelitian ini tidak semua SGB dilakukan pemeriksaan pungsi lumbal dikarenakan onset saat pasien datang ke RSCM masih di minggu pertama. Adanya disosiasi sitoalbuminologik akan terlihat setelah minggu kedua.

Kasus SMA ditemukan $11(8,4 \%)$ pasien. Ditemukan lebih banyak SMA tipe 1 dibandingkan SMA tipe 2 meskipun jumlahnya tidak berbeda terlalu jauh. Berdasarkan kepustakaan, SMA tipe 1 terjadi 75\% dan tipe $225 \%$. Perbedaan tersebut dapat disebabkan pasien SMA tipe 1 mungkin tidak terdiagnosis sejak awal dan telah mengalami kematian. Sementara SMA tipe 2 memiliki prognosis yang lebih baik sehingga laju ketahanan hidupnya menjadi lebih baik.

Dari seluruh SMA, terdapat 3 pasien yang telah terbukti secara analisis DNA. Kelainan neuromuskular 
Mia Milanti Dewi dkk: Prevalensi, spektrum klinis dan gambaran neurofisiologi kasus neuromuskular

Tabel 3. Spektrum neurofisiologi (KHS) yang khas pada kasus neuromuskular

\begin{tabular}{|c|c|c|c|c|c|c|c|c|}
\hline \multirow[t]{3}{*}{ Diagnosis } & \multicolumn{6}{|c|}{ KHS } & \multirow[t]{3}{*}{ F Wave } & \multirow[t]{3}{*}{ RNS } \\
\hline & \multicolumn{3}{|c|}{ Motorik } & \multicolumn{3}{|c|}{ Sensorik } & & \\
\hline & $\begin{array}{c}\text { Latensi } \\
\text { distal }\end{array}$ & Amplitudo & Velocity & $\begin{array}{c}\text { Latensi } \\
\text { Distal }\end{array}$ & Amplitudo & Velocity & & \\
\hline SMA & $\mathrm{N}$ & $\downarrow \downarrow$ & $\mathrm{N}$ & $\mathrm{N}$ & $\downarrow \downarrow$ & $\mathrm{N}$ & $\mathrm{N}$ & \\
\hline SGB tipe AIDP & $\uparrow \uparrow$ & $\mathrm{N}$ & $\uparrow \uparrow$ & $\mathrm{N}$ & $\mathrm{N}$ & $\mathrm{N}$ & $\uparrow \uparrow$ & \\
\hline SGB tipe AMAN & $N / \uparrow$ & $\downarrow$ & $\mathrm{N}$ & $\mathrm{N}$ & $\mathrm{N}$ & $\mathrm{N}$ & $\mathrm{N}$ & \\
\hline SGB tipe AMSAN & $N / \uparrow$ & $\downarrow$ & $\mathrm{N}$ & $\mathrm{N}$ & $\downarrow$ & $\mathrm{N}$ & $\mathrm{N}$ & \\
\hline CIDP & $\uparrow$ & $\downarrow$ & $\uparrow$ & $\mathrm{N}$ & $\downarrow$ & $\mathrm{N}$ & $\mathrm{N}$ & \\
\hline CMT & $\mathrm{N}$ & $\downarrow$ & $\mathrm{N}$ & $\mathrm{N}$ & $\downarrow$ & $\mathrm{N}$ & $\mathrm{N}$ & \\
\hline Bell's palsy & $\mathrm{N}$ & $\downarrow$ & $\downarrow$ & $\mathrm{N}$ & $\mathrm{N}$ & $\mathrm{N}$ & $\mathrm{N}$ & \\
\hline Erb’s palsy & $\uparrow$ & $\downarrow$ & $\downarrow$ & $\mathrm{N}$ & $\mathrm{N}$ & $\mathrm{N}$ & $\mathrm{N}$ & \\
\hline Neuropati perifer & $\mathrm{N}$ & $\downarrow$ & $\mathrm{N} / \downarrow$ & $\mathrm{N}$ & $\mathrm{N} / \downarrow$ & $\mathrm{N}$ & $\mathrm{N}$ & \\
\hline MG & $\mathrm{N}$ & $\mathrm{N}$ & $\mathrm{N}$ & $\mathrm{N}$ & $\mathrm{N}$ & $\mathrm{N}$ & $\mathrm{N}$ & + \\
\hline Miotonia kongenital & $\mathrm{N}$ & $\mathrm{N}$ & $\mathrm{N}$ & $\mathrm{N}$ & $\mathrm{N}$ & $\mathrm{N}$ & $\mathrm{N}$ & \\
\hline DMD & $\mathrm{N}$ & $\mathrm{N}$ & $\mathrm{N}$ & $\mathrm{N}$ & $\mathrm{N}$ & $\mathrm{N}$ & $\mathrm{N}$ & \\
\hline LGMD & $\mathrm{N}$ & $\mathrm{N}$ & $\mathrm{N}$ & $\mathrm{N}$ & $\mathrm{N}$ & $\mathrm{N}$ & $\mathrm{N}$ & \\
\hline Miositis & $\mathrm{N}$ & $\mathrm{N}$ & $\mathrm{N}$ & $\mathrm{N}$ & $\mathrm{N}$ & $\mathrm{N}$ & $\mathrm{N}$ & \\
\hline
\end{tabular}

Keterangan : N : normal; $\downarrow$ : menurun; $\uparrow:$ memanjang; + : abnormal, RNS: repetitive nerve stimulation.

Tabel 3 menunjukkan gambaran konduksi hantaran saraf (KHS) yang khas pada masing-masing kelainan neuromuskular

Tabel 4. Spektrum neurofisiologi (EMG) yang khas pada kasus neuromuskular

\begin{tabular}{lcccccccc}
\hline Diagnosis & \multicolumn{1}{c}{ EMG } \\
\cline { 2 - 8 } & \multicolumn{3}{c}{ Aktivitas spontan } & \multicolumn{1}{c}{ MUAP } \\
\cline { 2 - 9 } & Fibrilasi & PSW & Polifasik & Fasikulasi & Amplitudo & Durasi & Rekruitmen & $\begin{array}{c}\text { Interference } \\
\text { pattern }\end{array}$ \\
\hline SMA & +++ & ++ & +++ & ++ & $\uparrow \uparrow$ & $\mathrm{N} / \uparrow$ & $\downarrow \downarrow$ & $\downarrow$ \\
SGB tipe AIDP & ++ & ++ & ++ & - & $\mathrm{N} / \uparrow$ & $\mathrm{N}$ & $\mathrm{N} / \downarrow$ & $\mathrm{N} / \downarrow$ \\
SGB tipe AMAN & ++ & ++ & ++ & - & $\mathrm{N} / \uparrow$ & $\mathrm{N}$ & $\mathrm{N} / \downarrow$ & $\mathrm{N} / \downarrow$ \\
SGB tipe AMSAN & ++ & ++ & ++ & - & $\mathrm{N} / \uparrow$ & $\mathrm{N}$ & $\mathrm{N} / \downarrow$ & $\mathrm{N} / \downarrow$ \\
CIDP & ++ & ++ & ++ & - & $\uparrow$ & $\mathrm{N}$ & $\downarrow$ & $\downarrow$ \\
CMT & ++ & ++ & ++ & - & $\uparrow$ & $\mathrm{N}$ & $\downarrow$ & $\downarrow$ \\
Miotonia kongenital & - & - & - & - & & & & $\mathrm{N}$ \\
& & & $($ Bomber & & $\downarrow$ & $\mathrm{N}$ & $\mathrm{N}$ & \\
DMD & & & sound) & & & & & $\mathrm{N}$ \\
LGMD & + & +++ & - & - & $\downarrow$ & $\mathrm{N}$ & $\mathrm{N}$ & $\mathrm{N}$ \\
\hline
\end{tabular}

Keterangan : N : normal; $\downarrow$ : menurun; $\uparrow:$ memanjang; + : Ada; ++ : Meningkat; +++: Sangat Meningkat. Tabel 4 menunjukkan gambaran khas elektromiografi pada masing-masing kelainan neuromuskular.

lain yang banyak dijumpai di RSCM adalah neuropati $(51,1 \%)$. Etiologi neuropati dan usia terjadinya neuropati sangat bervariasi. Neuropati dapat terjadi sejak lahir hingga remaja. Brachialis plexus injury ataupun Erb's palsy sering ditemukan akibat dari trauma lahir. Neuropati yang sering terjadi dapat disebabkan penga- ruh obat pada penderita keganasan. Obat yang sering menyebabkan neuropati adalah vincristin. Neuropati yang didapat, seperti adanya trauma pada ekstremitas juga sering dijumpai. Berbagai jenis trauma, seperti trauma listrik, benda tumpul atau akibat benturan keras dapat menyebabkan neuropati. 


\section{Kesimpulan}

Kesimpulan penelitian ini didapatkan kelainan neuromuskular sebanyak 2,6\% dari seluruh pasien yang datang berobat ke Poli Saraf Anak RSCM. Kelainan neuromuskular sering dijumpai pada pasien di Poli Neurologi RSCM yang dapat mengakibatkan kesakitan dan kematian. Beberapa jenis kelainan neuromuskular dapat didiagnosis dengan melihat gejala klinis dan pemeriksaan fisis serta neurologis. Perlu dilakukan penelitian lebih lanjut untuk melihat luaran kasus-kasus neuromuskular pada anak di Indonesia.

\section{Daftar pustaka}

1. Deisch JR. Muscle \& nerve development in health \& disease. Dalam: Swaiman KF, Ashwal S, Ferriero DM, Schor NF, Finkel RS, Gropman AL, dkk, penyunting. Pediatric Neurology. Edisi ke-6. Cina: Elsevier Saunders; 2017. h.1029-37.

2. Finkel RS. Clinical assessment of pediatric neuromuscular disorders. Dalam: Swaiman KF, Ashwal S, Ferriero DM, Schor NF, Finkel RS, Gropman AL, dkk penyunting. Pediatric Neurology. Edisi ke-6. Cina: Elsevier Saunders; 2017. h.1029-37.

3. Romiti PA, Zhu Y, Puzhankara S, James KA, Nabuker SK,Zamba KD, dkk. Prevalence of Duchenne and Becker muscular dystrophies in the United States. Pediatric 2015;135:513-21.

4. Chung B, Wong V. Prevalence of neuromuscular diseases in
Chinese children: a study in southern China. J Child Neurol 2003;18:217-9.

5. Woodcock IR, Fraser L, Norman P, Pysden K, Manning S, Childs AN. The prevalence of neuromuscular disease in the pediatric population in Yorkhshire, UK; variation by ethnicity and deprivation status.Dev Med Child Neurol 2016,58:877-83.

6. Darras BT, Monani UR, De Vivo DC. Genetic disorders affecting the motor neuron: spinal muscular atrophy. Dalam: Swaiman KF, Ashwal S, Ferriero DM, Schor NF, Finkel RS, Gropman AL, dkk, penyunting. Pediatric Neurology. Edisi ke-6. Cina: Elsevier Saunders; 2017.h.1057-64.

7. Wilmshurst JM. Diagnosis dan management of pediatric peripheral neuropathies in resource-poor setting. Future Neurol 2013;8:133-148.

8. Rabie M, Ashwal S, Nevo Y. Inflammatory neuropathies. Dalam: Swaiman KF, Ashwal S, Ferriero DM, Schor NF, Finkel RS, Gropman AL, dkk, penyunting. Pediatric Neurology. Edisi ke-6. Cina: Elsevier Saunders; 2017. h.1085-91.

9. Flanigan K. Duchenne and Becker muscular dystrophies. Dalam: Swaiman KF, Ashwal S, Ferriero DM, Schor NF, Finkel RS, Gropman AL,dkk penyunting. Pediatric Neurology. Edisi ke-6. Cina: Elsevier Saunders; 2017. h.1106-11.

10. Kang PB, Mercuri E. Laboratory assessment of the child with suspected neuromuscular disorders. Dalam: Swaiman KF, Ashwal S, Ferriero DM, Schor NF, penyunting. Pediatric Neurology. Edisi ke-6. Cina: Elsevier Saunders; 2017. h.103843.

11. Willison HJ, Jacobs BC, van Doorn PA. Guillain Barre Syndrome. Lancet 2016;388:717-27. 